\title{
Anti-smoking critic wins campaigning right
}

Rex Dalton, San Diego

Supporters of the US tobacco industry have failed to silence one of its most prominent academic critics.

An appeals court in California has ruled that Stanton Glantz, a professor of medicine at the University of California at San Francisco (UCSF), can use his position to back the state government's anti-smoking efforts.

In 1997, Californians for Scientific Integrity - a group set up at a Sacramento attorney's office by the industry-sponsored National Smokers Alliance — sued Glantz in an attempt to stop him using his academic position to help the state of California fight smoking.

The group alleged that Glantz's 15 years of campaigning was a misuse of public funds. It also charged that the university's approval of his activities was a violation of the rights of those Californians who did not agree with the anti-smoking cause.

But two weeks ago, a three-judge panel of the Third District Court of Appeals in Sacramento rejected the allegations, reaffirming the right of any faculty member at the University of California to campaign against smoking.

"It makes me very glad to work at a uni-

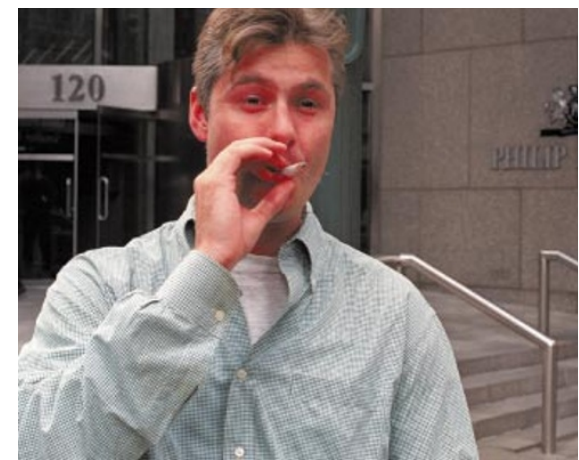

Last gasp? A Florida jury recently awarded \$145 billion in damages against tobacco companies.

versity that takes academic freedom and public interest very seriously and has the courage to stand up to ... the tobacco industry," said Glantz, who is widely known for challenging the industry's claims that it was unaware of the dangers of smoking.

Citing statements on a recruitment flyer, he claims that Californians for Scientific Integrity "was set up for the express purpose of suing the University of California and silencing me".

"It was clear intimidation," he adds. "But this shows you can stand up and beat them."
Mark Perry, a Washington DC-based attorney with the firm of Gibson, Dunn and Crutcher that represents the suing group, did not answer a request for comment. Perry has said separately that no decision has been reached on whether to appeal to the California Supreme Court.

Nor was there a response from the Claremont Institute, a conservative think-tank in California that filed a 'friend of the court' brief in support of the group.

Although the decision only addresses the rights of university staff to campaign against smoking, it could be far-reaching. Along with other cases, any faculty member of a Californian public university could use it to affirm his or her right to campaign for any cause endorsed by the state legislature.

Last month, Glantz, who conducts research in UCSF's cardiology division, won the annual Public Service Achievement Award of the lobby group Common Cause for his "tireless and tenacious" efforts against smoking. In the past, pro-smoking groups have attacked him in both California and Washington - accusing him of falsifying a result in a study of the effects of 'secondhand smoke', and seeking to cut off his research funds. 